\title{
Optimalisasi Obyek Wisata Terpadu Pendidikan Taman Tekno Kincir Angin Melalui Peningkatan Daya Tarik dan Partisipasi Masyarakat Di Pantai Panjang Nagari Ketaping Padang Pariaman
}

\author{
Hasanuddin $\left.^{*}\right) 1$, Hendri Nurdin ${ }^{1}$, Mansurdin ${ }^{2}$, Waskito ${ }^{1}$ \\ 1Jurusan Teknik Mesin - Fakultas Teknik - Universitas Negeri Padang \\ 2Jurusan PGSD - Fakultas Ilmu Pendidikan - Universitas Negeri Padang \\ *)Corresponding author, $\equiv$ sanquansing55@ft.unp.ac.id \& hens2tm@ft.unp.ac.id
}

Revisi $12 / 07 / 2019$;

Diterima 16/08/2019

Publish 05/09/2019

Kata kunci: Pesisir Pantai, Taman Tekno Kincir, Wisata Terpadu Pendidikan, Penerapan Teknologi

\begin{abstract}
Abstrak
Ketiadaan inovasi di dalam pengembangan kepariwisataan, khususnya untuk teknologi dan rekayasa daya tarik kunjungan telah membuat profil dan karakteristik usaha industri pariwisata ini, termasuk di Sumatera Barat masih mengalami stagnasi dan hambatan kemajuan. Keberadaan potensi sumberdaya wisata alam pantai yang ada, perlu diberi suatu daya tarik tersendiri agar dapat meningkatkan jumlah kunjungan, di antaranya mengembangkan konsep pariwisata terpadu pendidikan dengan membangun suatu daya tarik buatan yang dapat memberikan makna tujuan ganda "berwisata dan belajar" pada daerah tujuan wisata (DTW) yang ada. Mendirikan suatu taman tekno kincir angin (windmill techno park) sebagai suguhan bentuk wisata terpadu pendidikan (vokasi \& teknologi) khususnya bagi kalangan siswa/mahasiswa adalah sebuah jawaban, yang perlu pula diberikan suatu imbuhan dekoratif keindahan taman melalui pembangunan prasarana dan sarana fisis pendukung dan peran serta masyarakat sekitar obyek wisata yang bersifat mengoptimalkan tampilan daya tarik dan kepuasan bagi pengunjung. Pada gilirannya hal ini akan menimbulkan motivasi kedatangan \& membawa pada peningkatan jumlah kunjungan sekaligus memberikan dampak ekonomi (multiplier effect) segi pendapatan dan/atau tenaga kerja terhadap masyarakat di sekitar lokasi wisata, khususnya di negari Pantai Panjang Nagari Ketaping Kecamatan Batang Anai Kabupaten Padang Pariaman
\end{abstract}




\section{Suluah Bendang: Jurnal Ilmiah Pengabdian Kepada Masyarakat}

Vol.19, No.2, 2019

Hasanuddin , Hendri Nurdin, Mansurdin, Waskito

\section{PENDAHULUAN}

Pengembangan kepariwisataan di banyak tempat di Indonesia termasuk di daerah Sumatera Barat masih mengalami banyak masalah dan tantangan, sehingga sejumlah potensi dan ragam anugerah sumberdaya (resources endowment) yang ada tidak kunjung menggeliat dan dapat berperan menjadi pemacu dan penggerak utama (primemover role) pertumbuhan perekonomian wilayah masyarakat. Tempat-tempat kunjungan \& obyek wisata masih stagnasi dan lamban bergerak sehingga belum menjadi pilihan utama bagi para wisatawan baik nasional maupun internasional.

Di dalam RPJMN 2015-2019 pemerintah telah menetapkan target kunjungan wisatawan mancanegara hingga 20 juta orang sampai dengan tahun 2019 (Nasional, 2014). Namun sayangnya, hingga saat ini belum ada suatu peta jalan (roadmap) yang jelas terkait strategi pengembangan sektor pariwisata dalam lima tahun ke depan guna dapat mencapai target tersebut. Sekaitan dengan itu, menurut Core Indonesia, pemerintah telah mengeluarkan paketpaket kebijakan, di antaranya paket kebijakan bebas visa bagi 30 negara untuk kunjungan singkat/wisata ke Indonesia (Core Indonesia, 2016). Kebijakan ini diharapkan akan dapat menarik lebih banyak jumlah wisatawan dari manca negara untuk berkunjung ke Indonesia, sehingga dapat mendongkrak penerimaan devisa. Pada tingkatan kepengambilan kebijakan di daerah diperlukan kecerdasan inovatif untuk menggali potensi sumberdaya wisata dan mengembangkannya secara keterpaduan antar dinas intansi terkait sehingga dapat memberikan nilai dan keberlanjutan terhadap kesejahteraan masyarakat.

Di Indonesia sektor pariwisata masih mengalami banyak masalah dan tantangan, tidak terkecuali di daerah Sumatera Barat. Sejumlah potensi dan berbagai anugerah sumber daya pariwisata yang ada tidak terus meregang dan belum memainkan peran sebagai pengemudi dan pendorong utama pertumbuhan ekonomi nasional. Tempat-tempat kunjungan dan atraksi masih terlihat stagnan dan bergerak perlahan sehingga belum menjadi pilihan utama bagi wisatawan dari luar negeri (Core Indonesia, 2016). Ada banyak kawasan wisata alam umumnya, termasuk daerah pesisir sebagai bagian dari daerah sub-urban dan pengembangan / tujuan wisata belum berfungsi secara optimal sebagai daerah pedalaman untuk pengembangan dan pertumbuhan daerah perkotaan. Seperti diketahui, salah satu faktor eksternal yang akan mempengaruhi perkembangan kota adalah hubungannya dengan kota-kota perkotaan lainnya, serta relevansinya dengan daerah pedalaman termasuk daerah pedesaan sekitarnya dan potensi sumber daya terkaitnya (Soegijoko, 2017).

Pantai Panjang Nagari Ketaping di wilayah Kecamatan Batang Anai Kabupaten Padang Pariaman memiliki objek wisata alam berupa pesona pemandangan alam pantai \& lautan sebagai daya tarik alam dan potensi sumberdaya dengan hembusan angin yang dapat dikombinasikan pengembangannya sebagai suatu objek wisata atau daerah tujuan wisata (DTW). Kondisi yang ada selama ini pada daerah tujuan wisata tersebut belum banyak tersentuh pembangunan seperti halnya daerah tujuan wisata di daerah lainnya. Lokasi tujuan wisata masih terlihat bersifat naturalistik dan belum menjadi skala perioritas pembangunan kepariwisataan pemerintah daerah. Untuk itu, didasarkan atas kepemilikan potensi yang ada telah dilakukan salah satu solusinya yaitu mengembangkan model wisata terpadu pendidikan perantaraan referensi/acuan kunjungan berupa Taman Tekno Kincir Angin seperti ditunjukkan sebagian tampilan fisisnya pada Gambar 1. 


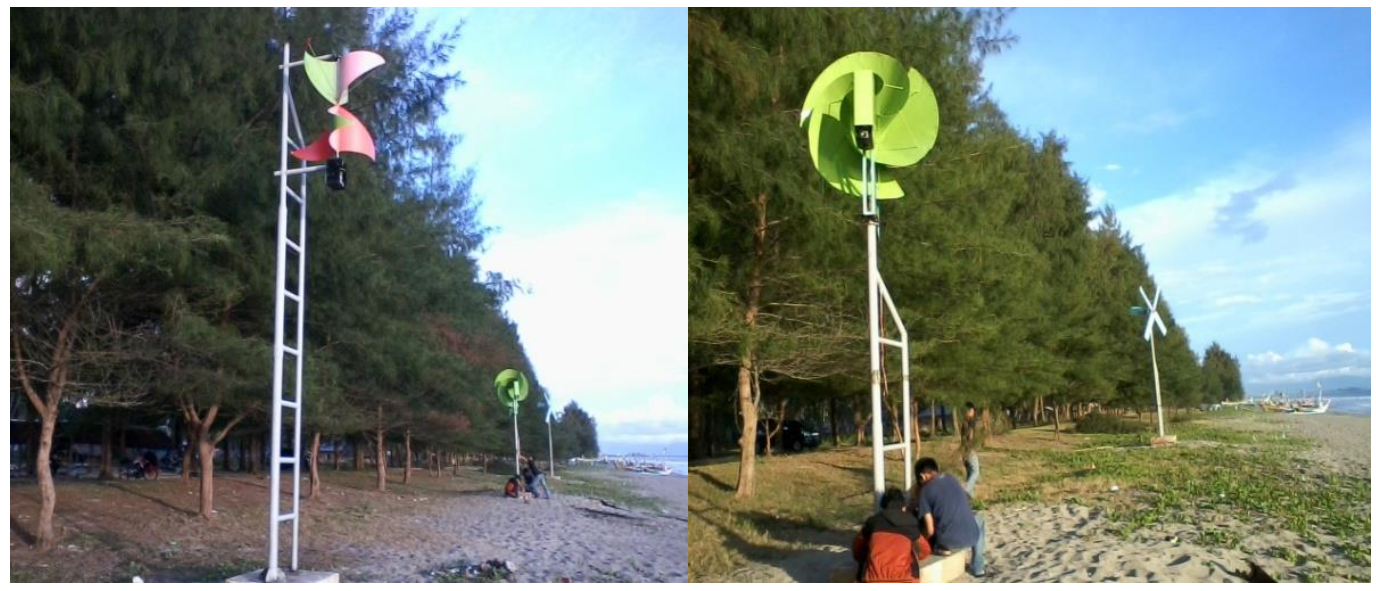

Gambar 1. Tampilan Fisis Taman Tekno Kincir Angin di Areal Lokasi Pantai Panjang Nagari Ketaping Pariaman

Secara kesisteman, kepariwisataan adalah bagian dari pengembangan wilayah yang berkaitan dengan pembangunan dan pengembangan tata ruang (tata ruang wilayah/RTW) sesuatu kawasan sehingga menjadikannya sebagai daerah tujuan wisata (DTW). Adapun istilah kepariwisataan secara luas akan mencakup segala aspek yang terkait dengan kepentingan dan pengelolaan dunia industri pariwisata, baik aspek pengembangan fisik (sarana dan prasarana infrastruktur) dan non fisik (manusia dan tatanan kemasyarakatan), serta keramahtamahan hostapitality industri). Dalam konteks perwilayahan keberadaan landscape alam adalah sebagai sumberdaya wisata yang akan berkontribusi terhadap pembangunan daerah melalui pembangunan dan pengembangan obyek-obyek wisata dimana pada gilirannya memberikan kontribusi bagi pertumbuhan ekonomi wilayah dan masyarakat. Kondisi ini terkait dengan pengembangan pariwisata pesisir yang berkelanjutan. Kebutuhan kebijakan dan strategi dalam menerapkan konsep pengelolaan sumber daya pesisir terpadu \& berkelanjutan (Clark, 2018).

Secara aspek fisis kondisi yang ada saat ini merupakan hasil dari implementasi kegiatan dan pengembangan yang telah dilakukan sebelumnya. Dari kondisi tersebut terlihat belum dapat memikat motivasi wisatawan untuk mengunjunginya, antara lain disebabkan belum adanya unsur tambahan asesori keindahan taman. Terlihat tampilan fisis taman tekno kincir angin yang didirikan sebatas penempatan pohon-pohon kincir angin dan belum optimal memberikan kesan taman kunjungan secara dekoratif. Artinya, sebagai produk kepariwisataan taman wisata ini masih membutuhkan sejumlah fasilitas tambahan (sarana dan prasarana pendukung) sehingga lebih menimbulkan nuansa layaknya sebuah taman rekreasi. Diperlukan sejumlah daya tarik tambahan, membenahi dan membangun fasilitas seperti arena bermain \& permainan anak-anak, bangku-bangku taman, fasilitas taman lainnya yang bermuatan pendidikan dan membangkitkan fantasi anak serta motivasi kunjungan.

Salah satu upaya untuk meyiasati dan menyikapi permasalahan tersebut di antara lain memperkenalkan model kepariwisataan vokasi dan teknologi yang bernuansa wisata terpadu pendidikan melalui pembangunan Taman Tekno Kincir Angin (Windmill Techno Park). Model ini dilakukan berlandaskan pada salah satu faktor pertimbangan di dalam memajukan dan mengembangkan kepariwisataan yang terkait pada faktor daya tarik "something to see". Hal ini juga tidak terlepas atas keberhasilan dan kemajuan kepariwisataan yang dicapai oleh negara tetangga Malaysia dengan program Wisata Perpelancongan Pelajar dan model Wisata budaya 


\section{Suluah Bendang: Jurnal Ilmiah Pengabdian Kepada Masyarakat}

Vol.19, No.2, 2019

Hasanuddin , Hendri Nurdin, Mansurdin, Waskito

dan ritual etnik segi budaya negara kunjungan (Islam dan China) yang dikelola oleh kepariwisataan Negara Thailand (Core Indonesia, 2016).

Di samping itu, segi aspek lokasional dari hasil observasi juga menunjukkan wilayah ini mulai berkembang dan dimungkinkan menjadi pusat pertumbuhan yang memacu munculnya usaha ekonomi masyarakat sekitar obyek wisata. Selain itu terbukanya akses transportasi/lalu lintas perdagangan antar wilayah Kota Padang ke Pariaman dan sekitarnya (Hasanuddin, Nurdin, Waskito, \& Refdinal, 2018).

Menurut (Suwantoro, 1997), pola kebijakan pengembangan suatu daerah tujuan wisata hendaknya meliputi, (a) Perioritas pengembangan obyek, (b) Pengembangan pusat- pusat penyebaran kegiatan wisatawan, dan (c) Memungkinkan kegiatan penunjang pengembangan obyek wisata. Sedangkan menurut (Yoeti, 2008), suatu tujuan pariwisata harus meliputi lima unsur yang penting agar wisatawan dapat merasa puas dalam menikmati wisatanya yaitu (a) obyek wisata dan atraksi, (b) tersedianya fasilitas sarana wisata, (c) terdapatnya prasarana pendukung, (d) transportasi dan akses keterjangkauan, (e) Keramahtamahan dan hospitality penduduk setempat

Dalam meningkatkan eksistensi keberadaan fungsional wilayah atau lokasi yang dapat dikembangkan oleh masyarakat di kenagarian Ketaping khususnya di sekitar pantai Ketaping, menjadikan konsep yang ingin diwujudkan. Selama ini masyarakat belum maksimal memanfaatkan wilayah pantai yang sangat dimungkinkan untuk dijadikan objek wisata, terlebih lagi bernuansa wisata pendidikan. Keberadaan nuansa dan fenomena pesisir pantai ketaping yang menjadikan sasaran program sehingga memiliki peran dan fungsi sebagai model wisata vokasi \& teknologi yang dapat memberikan dampak pada peningkatan jumlah pengunjung dan ekonomi masyarakat mitra.

Untuk melihat seberapa jauh prospek pembangunan obyek wisata terpadu pendidikan Taman Tekno Kincir Angin, di dalam konteks analisis pembangunan wilayah, di antara lain dapat dilihat dari segi potensi dan interaksinya secara lokasional terhadap wilayah sekitar melalui model teknik analisis gravitasi. Sebagaimana dalam teori kutub pertumbuhan, daerah tujuan wisata (DTW) atau kawasan kunjungan Wisata (KKW) dapat berperan sebagai pusatpusat pertumbuhan termasuk fungsinya sebagai daerah belakang atau penyangga (hinterland) untuk kemajuan dan pertumbuhan sebuah kota.

Dalam rangka untuk pengembangan dan pembinaan kepariwisataan di Indonesia, pemerintah telah merumuskan batasan tentang wisatawan, bahwa "wisatawan (tourist) adalah setiap orang yang bepergian dari tempat tinggalnya untuk berkunjung ke tempat lain dengan menikmati perjalanan dan kunjungannya. Kepariwisataan tumbuh karena perbedaan, keunikan, kelokalan baik berupa pemandangan \& pesona alam, keanekaragaman flora \& fauna maupun yang berupa kebudayaan sebagai hasil cipta, karsa, rasa dan budi manusia, termasuk tentunya taman kincir angin (windmill tecno park). Tanpa perbedaan itu, tak akan ada kepariwisataan, tidak ada orang yang melakukan perjalanan atau berwisata.

Pariwisata pendidikan, merupakan suatu program yang menggabungkan unsur kegiatan wisata dengan muatan pendidikan di dalamnya. Program ini dikemas sedemikian rupa menjadikan kegiatan wisata tahunan atau kegiatan ekstrakulikuler yang memiliki kualitas dan berbobot. Materi-materi dalam pemanduan telah disesuaikan dengan bobot pembelajaran dan kurikulum pendidikan. Setiap kali mengunjungi obyek wisata akan disesuaikan dengan 
ketertarikan obyek dan bidang ilmu yang akan dipelajari. Diharapkan dari kegiatan ini dapat diperoleh pengembangan obyek wisata pendidikan melalui kincir angin.

Program yang dikembangkan ini dapat berupa ecowisata (ecotourism), wisata warisan (heritage torism), wisata pedesaan/pertanian (rural atau farm tourism), wisata komunitas (community tourism), dan pertukaran antar siswa sekolah (student exchnge tourism). Program tersebut tentunya perlu direncanakan \& mengemas aspek potensi wisata dengan kebijakan dan pengembangan yang dapat memberikan suatu nuansa wisata \& pengalaman belajar bermakna tertentu terhadap setiap pengunjung/wisatawan misalnya melalui pengenalan taman kincir angin (windmill techno park) pada kawasan pantai sebagai salah satu program techno tourism di dalam konteks wisata pendidikan (edutourism).

Idealnya sebuah wisata pendidikan yang selama ini telah lama berjalan, didesain khusus untuk memenuhi kapasitas ilmu pengetahuan para siswa dan mahasiswa untuk mengisi wawasan kebangsaan melalui kegiatan perjalanan, mengenal wilayah dan potensi sumber daya lokal antar kabupaten, provinsi serta antar pulau di Indonesia. Kegiatan perjalanan dalam tur wisata pendidikan akan berdampak luas bagi pengembangan ekonomi di daerah karena dapat mendukung pergerakan ekonomi rakyat sekaligus membuka kantong-kantong seni dan budaya yang perlu diketahui pelajar. Sangat diharapkan kegiatan wisata pendidikan dapat menjadi sarana untuk melestarikan budaya dan mengenalkan nilai luhur sejarah dan budaya bangsa Indonesia.

Dalam hal peningkatan daya saing pariwisata perlu langkah yang proaktif dan terobosan yang inovatif di dalam mengembangkan suatu daya tarik dan pesona kunjungan tersendiri, misalnya membangun suatu paradigma (konsep pemikiran) tentang pertamanan teknologi "windmill techno park" untuk pengelolaan sebuah wisata pendidikan (edutourism) pada suatu kawasan kunjungan wisata. Secara lebih luas, melalui kegiatan wisata di bidang pariwisata, termasuk wisata pendidikan akan berdampak banyak pada pembangunan ekonomi di kawasan, dan sekaligus membuka kantong seni dan budaya, termasuk kegiatan pemanfaatan dan pelestarian potensi sumber daya alam yang perlu diketahui wisatawan (Biederman \& Biederman, 2008), (Metro-Roland, Knudsen, \& Greer, 2016).

Berdasarkan kondisi yang disampaikan diperlukan pengembangan obyek wisata terpadu pendidikan (WTP) melalui suatu referensi obyek kunjungan berupa taman tekno kincir angin (windmill techno park/WTP) di kawasan pantai yang bernuansa dan bermakna teknologi. Sebagai pengembangan model vokasi perantaraan beserta fungsi kincir angin sebagai sistem konversi energi, sehingga memberikan suatu daya tarik wisata dan pembeda dibandingkan obyek wisata di daerah lainnya.

\section{METODE PELAKSANAAN}

Pelaksanaan Program Kemitraan Masyarakat ini dilaksanakan di kawasan pinggiran atau bibir Pantai Panjang di Nagari Kataping Kecamatan Batang Anai Kabupaten Padang Pariaman yang berjarak sekitar $35 \mathrm{~km}$ dari kampus Universitas Negeri Padang (UNP) yang berbatasan dengan lokasi Bandara Internasional Minangkabau. Pelaksanaan kegiatan program kemitraan masyarakat dilaksanakan setelah mendapat perizinan dari Wali Nagari dan perangkat desa dengan melibatkan tim pelaksana, kelompok masyarakat dan mahasiswa. Guna dapat merealisasikan tujuan Program Kemitraan Masyarakat ini diperlukan langkah dan atau teknik serta metode diantaranya:

\footnotetext{
Optimalisasi Obyek Wisata Terpadu Pendidikan Taman Tekno Kincir Angin Melalui Peningkatan Daya Tarik dan Partisipasi Masyarakat di Pantai Panjang Nagari Ketaping Padang Pariaman | 21
} 


\section{Suluah Bendang: Jurnal Ilmiah Pengabdian Kepada Masyarakat}

Vol.19, No.2, 2019

Hasanuddin , Hendri Nurdin, Mansurdin, Waskito

\section{Perencanaan Dekoratif Taman Tekno Kincir Angin}

Sembari melengkapi model-model konstruksi kincir angin lainnya beserta fungsionalnya untuk tambahan referensi aspek pembelajaran (educational focus on edutourism planning) maka untuk meningkatkan eksistensi keberadaan lokasi taman khususnya keindahan dan kenyamanan maka diperlukan desain bentuk dekoratif serta unsur komponen pendukung daya tarik (tourism focus on edutourism planning). Kebijakan keputusan dalam manajemen operasi terkait tindakan pemilihan proses dalam merealisasikan tindak operasional pengerjaan keputusannya dapat diserahkan pada tukang atau bersama mahasiswa, masyarakat dan tenaga ahli.

Terkait dengan pelaksanaan kegiatan tersebut seperti desain gambar akan dilengkapi, sekaligus terkait jenis komponen utama yang dibutuhkan, seperti asesori pertamanan, pembuatan kelengkapan aneka permainan fisik anak merangsang perkembangan dan pertumbuhan.

\section{Tahapan Dalam Metode}

Kegiatan ini direncanakan dalam bentuk penerapan Ipteks berupa pembuatan dan penerapan ipteks pengembangan daya tarik pariwisata. Adapun tahapan dalam metode, terdiri atas persiapan, pelaksanaan, pemantauan, dan evaluasi.Diawali dengan penjajagan dan observasi ke tengah masyarakat dalam mendapatkan kejelasan dan konsisi yang seutuhnya di lapangan, khususnya terkait lokasi taman sehingga penerapan ipteks dapat terlaksana dengan baik. Untuk kepentingan itu, dalam hal pengembangan fisik taman perlu pertimbangan terhadap keikutsertaan masyarakat sekitar.

Pada tahapan persiapan akan dilakukan koordinasi dengan lembaga/pihak terkait (perangkat desa/wali nagari), terutama dalam menentukan lokasi kegiatan dan jadwal pelaksanaannya. Di pihak lain tim pelaksana kegiatan dalam tahapan ini melakukan persiapan bahan dalam menerapkan teknologi dan peralatan yang diperlukan, pendistribusian tugas ke masing-masing anggota dan persiapan ke lapangan serta evaluasi yang akan dipergunakan pada saat pematauan kegiatan.

Pada tahapan pelaksanaan adalah berupa penerapan teknologi melalui rancang bangun daya tarik buatan setelah dipersiapkan secara baik sesuai hasil perencanaan/desain pertamanan. Tim pelaksana melakukan rekayasa dan inovasi tambahan daya tarik taman dengan model sistem gabungan daya tarik alam pantai, ini akan lebih efektif dan efisien di dalam proses pengolahan. Penggunaan dan konsultasi jasa ahli pertamanan adalah lebih dimungkinkan guna mendapatkan hasil yang lebih representatif. Tentunya dalam hal ini sangat tergantung pada jumlah dana yang dapat disetuji oleh LP2M serta jenis komponen peralatan, bahan-bahan pertamanan yang direncanakan.Proses Pemantauan dan evaluasi dilakukan dengan jangka waktu yang telah ditentukan. Kegiatan ini dimaksudkan untuk melihat sejauh mana tujuan kegiatan dapat tercapai, terutama pada segi manfaat yang dirasakan dan dialami masyarakat setelah pelaksanaan program ipteks diterapkan.

Kegiatan pemantauan ini juga dilakukan melalui pengambilan data-data dari masyarakat tentang kebermanfaatan dan hasil penerapan teknologi yang telah dilaksanakan, terutama kaitannya dengan kegiatan pengolahan gula saka, 
Keterkaitan Program dan Rancangan Evaluasi melibatkan beberapa pihak atau lembaga dalam rangka memaksimalkan mekanisme kerja untuk mencapai tujuan. Adapun pihak-pihak yang terlibat seperti Perangkat nagari, sebagai pihak dan wadah pembangunan serta pengembangan kenagarian sehingga diharapkan nantinya dapat membantu proses pembinaan dan evaluasi kegiatan.

Sedangkan dari rancangan evaluasi, pada prinsipnya dilakukan sepanjang pelaksanaan kegiatan, baik diawal, saat kegiatan berlangsung, maupun akhir semua kegiatan telah selesai diselenggarakan. Melalui pendekatan kombinasi evaluasi kegiatan tersebut maka apabila selama kegiatan dapat terjadi segala kekurangan dan ketidaksempurnaan sesuai dengan tujuan yang ditetapkan dapat dilakukan pembenahan untuk perbaikan.

Adapun kreteria evaluasi di antara lain meliputi prihal, (a) Ketepatan pelaksanaan kegiatan dengan jadwal (b) Koordinasi dan mekansime kerja dalam tim pelaksana dengan unsur terkait (c) Tingkat motivasi dan partisipasi masyarakat, khususnya kelompok sasaran (pemanfaat) melalui observasi \& peningkatan jumlah, (d) Situasi, kondisi, dan interaksi tim pelaksana dengan masyarakat selama kegiatan berlangsung, (e) pengerjaan fisis taman dan ketersesuai rancangan dan pertimbangan dari pengguna (stakeholders).

Tak terlepas dari kegiatan pelaksanaan dan metode pada program pengabdian pada masyarakat ini adalah peran unsur bahan (material), jenis komponen peralatan, dan teknologi yang ditawarkan. Di dalam hal ini tergantung pada bentuk/penekanan pelaksanaan kegiatan, yaitunya ada yang bersifat fisik dan non fisik.

Pelaksanaan Kegiatan bersifat fisik, yang menyangkut pada proses pembangunan dan peningkatan daya tarik (dekorasi keindahan taman) taman tekno kincir angin. Bahan (material) yang digunakan antara lainnya, prasarana dan sarana kebutuhan taman seperti pembelian sejumlah jenis tumbuhan pohon \& bunga, pasir/koral \& semen, pagar lingkungan taman, bangku-bangku santai, dan sebagainya.

Tak kalah urgensinya dalam pertimbangan pengadaan sarana ini adalah ketersesuainnya sebagai model wisata terpadu pendidikan, maka dalam hal jika pendanaan mencukupi akan dilakukan pembangunan lingkungan taman dengan areal atau arena permainan dan hiburan kebutuhan anak-anak pendidikan usia dini (PAUD), Taman Kanak-Kanak seperti, bangku seluncuran, papan jingkrak, body sport, kereta api dan mobil-mobilan, dan sebagainya. Dengan adanya ketersediaan arena untuk pendidikan anak-anak ini maka ke depannya dimungkinkan mengembangkan model penyelengaraan "PAUD Terbuka Alam Pantai" untuk program wisata terpadu pendidikan yang dikelola oleh aparatur atau perangkat nagari.

Bentuk Pelaksanaan Kegiatan bersifat non fisis, dimana pelaksanaannya diarahkan pada unsur mengajak atau berperanserta ke masyarakat di sekitar obyek wisata dan aparatur pemerintah atau perangkat negari di dalam keikutsertaan proses pembangunan dekoratif taman dan lingkungannya. Memberikan penyuluhan akan fungsi dan tujuan keberadan taman tekno kincir angin sebagai obyek wisata pendidikan oleh tim pelaksana pengabdian dengan mengundang Dinas Instansi terkait.

\section{HASIL DAN PEMBAHASAN}

Pada Gambar 2. yang semulanya daerah tujuan wisata (DTW) pada lokasi tersebut hanya berupa potensi daya tarik wisata secara alami pemandangan bibir pantai \& lautan (natural landscape), kemudian dilakukan sinergi pengembangan dengan mengkombinasikan potensinya 


\section{Suluah Bendang: Jurnal Ilmiah Pengabdian Kepada Masyarakat}

Vol.19, No.2, 2019

Hasanuddin, Hendri Nurdin, Mansurdin, Waskito

melalui pembangunan susunan konstruksi kincir angin, sebagai daya tarik buatan (artificial attraction) sehingga menjadikannya sebuah obyek wisata bersifat terpadu pendidikan berupa Taman Tekno Kincir Angin. Sebagai daerah tujuan wisata tentunya, hasil pembangunan fisik taman tersebut perlu mendapat perhatian segi aspek lingkungan dan keindahan agar supaya lebih meningkatkan daya tarik bagi pengunjung, memberikan nilai (value) dan kesan pesona.
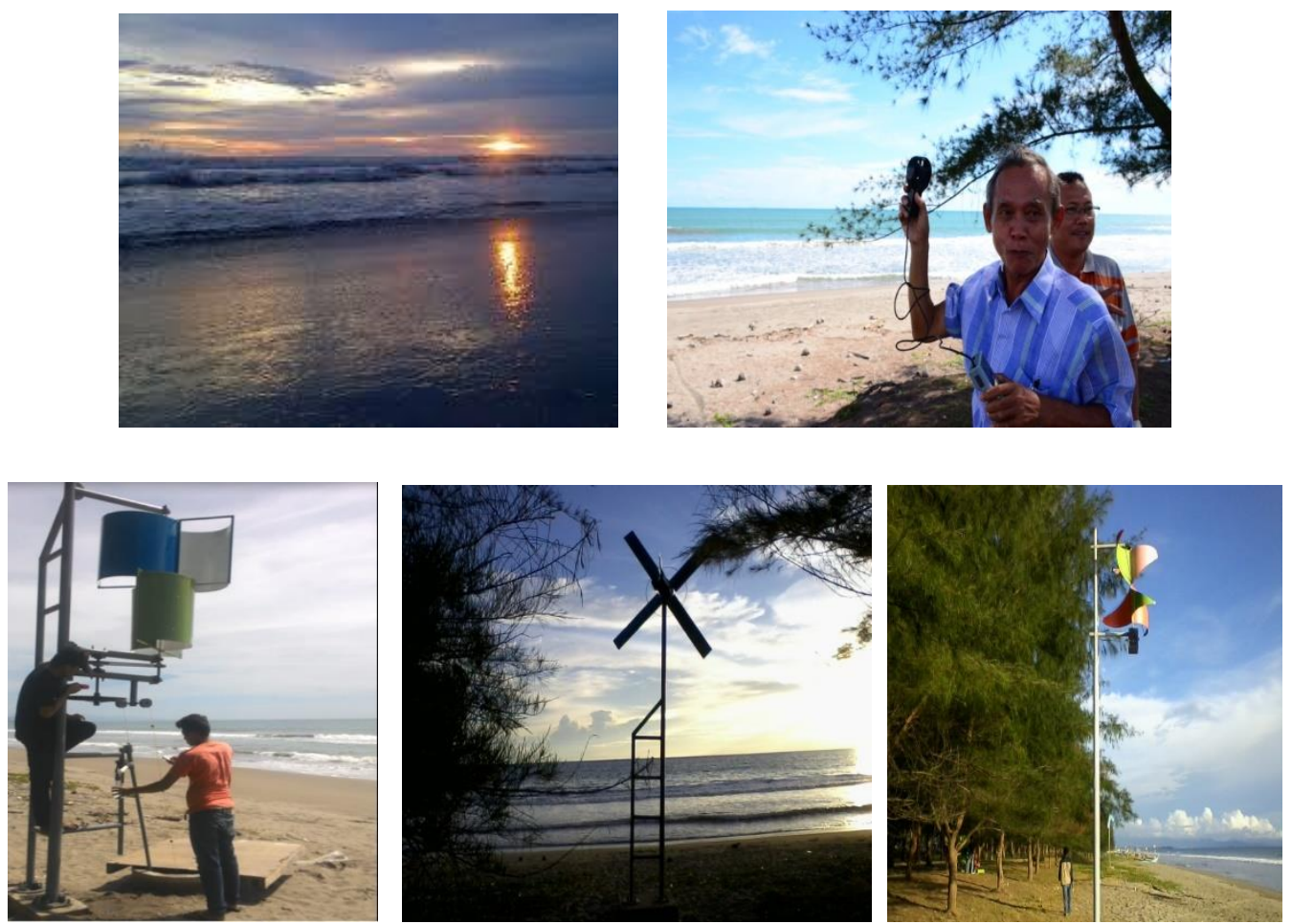

Gambar 2. Model Fisis Kincir Angin pada Hasil Tahun Pertama

\section{A. Optimalisasi Obyek Wisata dan Hasil Kegiatan Program}

Berdasarkan tujuan program pengabdian atau penerapan ipteks bagi masyarakat yang telah direncanakan sebelumnya, maka hasil yang dapat dicapai di dalam mengoptimalkan daya tarik kunjungan tidak terlepas dari alokasi pendanaan yang tersedia (disediakan). Adapun ketercapaian program dan hasil bidang/aspek fisis pembangunan antara lain adalah:

\section{Melengkapi Prasarana \& Sarana Taman dengan Fasilitas Bermain}

Sebagai sebuah daerah tujuan wisata (DTW), Pantai Ketaping selama ini belum banyak tersentuh pembangunan kepariwisataan, terutama fungsinya untuk lokasi rekreasi wisata. Memang sebelumnya pemerintah telah membangunan prasarana/infrastruktur jalan pinggiran pantai tetapi dewasa ini kondisinya termakan usia sehingga sudah banyak yang hancur dan perlu segera direhabilitasi. Di samping itu, dalam segi aspek lingkungan hidup pemerintah juga telah menanam pohon-pohon pelindung untuk menjaga agar bibir pantai tidak mengalami abrasi dari pukulan gelombang air laut. 
Pada bagian-bagian lokasi bibir pantai yang terbuka dan di sekitar pepohonan pelindung, dibangun dan ditempatkan kincir-kincir angin sehingga susunannya menjadikan/memberi nuansa sebuah taman yang disebut Taman Tekno Kincir Angin (Windmill Techno Park). Ini merupakan hasil dan upaya pemikiran untuk mengkombinasikan dua potensi sumberdaya pesisir yaitu berupa pemandangan alam pantai (coastal resources) dan potensi sumberdaya angin (kinetic energy) melalui perantaraan desain dan susunan kincir-kincir angin sehingga melahirkan suatu daya tarik wisata tersendiri. Model dan konsep pengembangan kepariwisataan seperti ini telah banyak dikemas dan dikembangkan oleh banyak Negara., seperti Negeri Belanda, Korea Selatan dan lainnya yang potensial akan potensi sumberdaya angin.

Walau hasil pembangunan yang dicapai belum optimal, namun demikian telah dapat menyuguhkan sebuah model pengembangan kepariwisataan. Untuk kebutuhan itu, seiring berjalan waktu perlu pembenahan dan peningkatan eksistensinya sebagai upaya mengoptimalisasi fungsi dimana secara aspek fisis antara lain dibutuhkan penambahan daya tarik dan pesona keindahan seperti melengkapi Taman Tekno dengan sarana bermain untuk anak-anak/pengunjung taman sebagaimana ditunjukkan dalam Gambar 3. Pemasangan dan penempatan sarana bermain anak berada dekat gapura yang di atasnya terlihat dari kejauhan kincir-kincir angin yang berputar, sehingga memberikan kesan bagi anak-anak yang lagi bermainan seluncuran \& jungkat-jungkit.
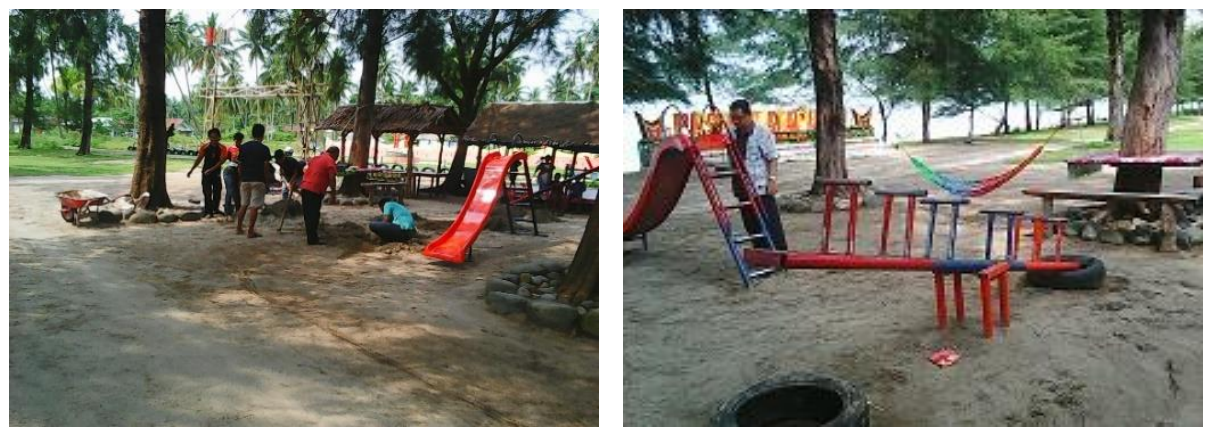

Gambar 3. Fasilitas Bermain Anak Usia Dini pada Taman Tekno Kincir Angin

Mengadakan fasilitas bermain bagi anak-anak dan keluarga pengunjung tersebut sangat urgen di dalam mengembangkan suatu daya tarik dan pesona wisata. Untuk sementara waktu sesuai ketersediaan dana, maka fasilitas \& sarana bermain yang dapat diadakan terdiri atas Seluncuran Anak-Anak dan Batang Jungkat-Jungkit. Di dalam pendidikan anak usia dini, aneka sarana permainan seperti ini banyak digunakan terutama bertujuan untuk membangun aspek fisik dan psikologi perkembangan anak. Kedepannya upaya melengkapi areal sekitar taman dengan aneka jenis prasarana dan sarana yang beraneka ragam akan menghasilkan suatu wacana Taman Wisata yang berisi muatan Pendidikan dalam kontek PAUD Terbuka (The Open Kindersgarden) Alam Pantai dimana nantinya akan dikelola oleh pihak pemerintahan desa.

Hasil pengamatan sementara pada lokasi sekitar desa Pantai Ketaping belum terlihat adanya usaha untuk pendidikan Anak Taman Kanak-Kanak (TK) ataupun upaya masyarakat di dalam mengembangkan institusi pendidikan PAUD tersebut. Sesuai dengan beruntuk dalam tujuan penelitian yaitu mengembangkan obyek wisata pendidikan, maka merencanakan dan mengembangkan suatu model wisata terpadu pendidikan tidak hanya berisi atau bersifat vokasi

Optimalisasi Obyek Wisata Terpadu Pendidikan Taman Tekno Kincir Angin Melalui Peningkatan Daya Tarik dan Partisipasi Masyarakat di Pantai Panjang Nagari Ketaping 


\section{Suluah Bendang: Jurnal Ilmiah Pengabdian Kepada Masyarakat}

Vol.19, No.2, 2019

Hasanuddin , Hendri Nurdin, Mansurdin, Waskito

dan teknologi belaka tetapi juga dapat dikemas dengan bidang dan tingkatan pendidikan/pembelajaran yang lainnya (berbeda-beda).

Berdasarkan wawancara dengan salah seorang anggota masyarakat sekaligus salah seorang warga memiliki usaha restoran sekitar lokasi taman dan juga tergabung sebagai anggota kelompok sadar wisata (Ibuk Tin), sempat tim anggota pengabdian menanyakan, bagaimana dengan hasil pemasangan fasilitas Bermain Anak-Anak ini Buk? Hasil pengamatan saya cukup antusias anak-anak memanfaatkannya, dan bahkan ibuk lihat mereka saling berebutan. Sayangnya, fasilitas tambahan untuk daya tarik ini masih terbatas jumlah dan jenisnya.

Pemantauan kegiatan pengabdian ketika berkunjung ke lokasi, terlihat anak-anak seusia PAUD bersama orangtuanya, siswa SMP/SMA serta pedagang keliling datang ke lokasi taman wisata Pantai Panjang Nagari Ketapiang. Memang kedatangan siswa-siswa tersebut berkunjung lebih banyak untuk senda gurau dan berphoto (selfie) bersama, dimana di antara mereka memanfaatkan kincir angin sebagai latar belakang untuk membuat kesan dan kenangan, terutama pada model kincir angin tradisional atau klasik ala Belanda.

\section{Melengkapi Prasarana \& Sarana Taman dengan Gapura}

Gapura atau gerbang tanda masuk ke areal obyek wisata terpadu pendidikan Taman tekno Kincir Angin, sebenarnya telah dibangun pada tahap awal kegiatan. Akan tetapi penempatan dan fungsinya belum representatif untuk sebuah gerbang masuk ke obyek wisata terutama kaitannya dengan sebagai sarana informasi dan komunikasi. Berdasarkan hasil kunjungan dan survei awal kegiatan pengabdian/penerapan ipteks ini, serta sesuai dengan pembicaraan permintaan dan permohonan pihak nagari/perangkat desa (wali korong) agar gerbang tanda masuk ke obyek wisata pendidikan tersebut, kalau bisa ditempatkan pada pinggiran jalan alternatif (Lintas Padang - Pariaman). Artinya, permintaan memindahkan gerbang yang sudah ada/lama atau pengadaan gerbang baru untuk kebutuhan informasi dan pemasaran tersebut. Di samping itu, perlu penambahan kincir angin pada bagian tepi pantai arah ke lokasi pasar ikan. Oleh karena program pengabdian/penerapan ipteks ini merupakan implementasi hasil penelitian, maka selain pemasangan gapura tersebut juga telah dilengkapi penambahan dua kincir angin, yaitu model klasik dan dual rotor seperti pada Gambar 4.
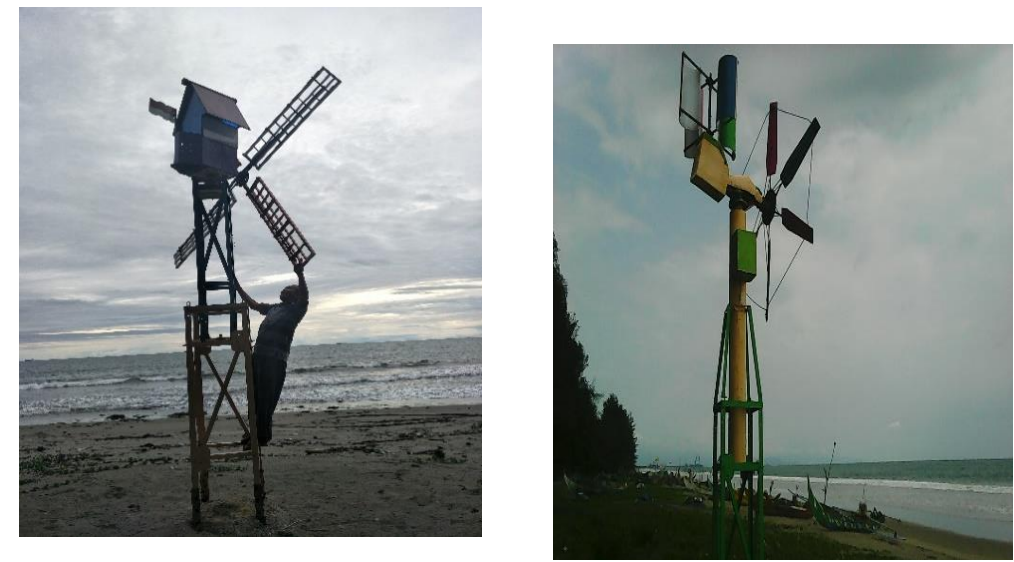

Gambar 4. Penambahan Dua Model Kincir Angin untuk Daya Tarik 
Menurut pendapat walikorong penambahan kincir ini akan menambah keindahan daerah kami (maksudnya obyek wisata pantai). Memang segi fungsional kincir ini dimanfaatkan untuk pembangkit energy listrik, tapi kami lebih suka akan manfaatnyan untuk pemandangan (demikian ujarnya). Kalau bisa perbaiki kincir yang tidak bekerja untuk memompa air yang telah terpasang sebelumnya. Saya lihat kincir angin Bapak kurang berputar pada lokasi sekarang, untuk itu maka ambo minta tadinyo di pindah ke arah lokasi dekat pasar ikan tersebut disitu lebih terbuka arealnya dan cukup bebas angin bergerak. Lebih lanjut selanya, dalam logat yang sama bahasa Minang/Piaman "Baa dek Apak kan iyo tu, cubo pintu muko/ruang tamu rumah awak bukak, tapi balakang nyo ndak ado tabukak, Ndak kan lalu angin ko do" Kami, tim pelaksana mengangguk-angguk, meng iyo kan “.

Dalam konteks kegiatan penelitian yang dijalankan, memang telah dilakukan pengukuran kecepatan angin di lokasi bibir pantai mulai dari daerah Manggopoh, Pantai tiram, Pasie Ujung, dan sekitarnya, dimana secara relative kecepatannya dapat memenuhi persyaratan untuk konversi energy kincir angin. Memilih lokasi penempatan awal mulai kegiatan awal penelitian tersebut cukup sulit dan menghadapi hambatan. Kemudian pertimbangan teknis, dan setelah dilakukan analisis secara aspek kewilayahan maka pemilihan areal pantai Ketapiang ini cukup mendukung dan potensial untuk wilayah pengembangan.

Bagaimanapun program rencana yang akan diterapkan ke tengah masyarakat, yang menjadi pokok pertimbangan esensialnya adalah menempatkan kebutuhan dan permintaan masyarakat dimana dalam hal ini dapat diwakili oleh pemerintah setempat bersama perangkat nagari. Untuk itu, dengan mempertimbangkan sejumlah batasan dan ketersediaan pendanaan, serta dengan penundaan/peniadaan sejumlah kegiatan dalam program maka dilakukan desain dan pembangunan gerbang baru (gapura) yang ditempatkan pada pinggiran jalan jalur alternative tersebut sebagaimana terlihat bentuk fisisnya dalam Gambar 5.

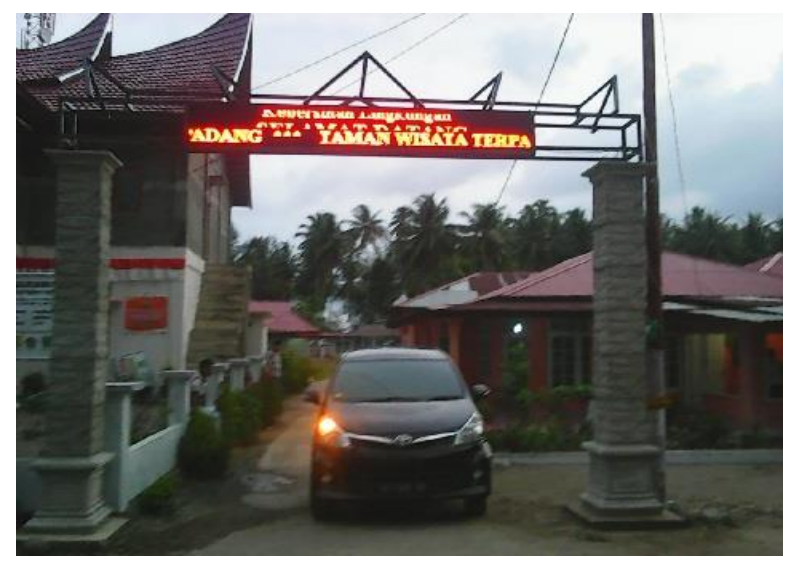

Gambar 5. Gerbang Tanda Masuk Taman Tekno Kincir Angin di Pantai Panjang Nagari Ketaping- Kab. Padang Pariaman

Berbeda halnya segi konstruksi gapura tahun sebelumnya, dimana bangun fisiknya dirancang menggunakan tiang penyangga dari bahan beton (coran + batu alam)dan dilengkapi dengan papan teks berjalan (running text) sebagai symbol keberadaan taman tekno dan pesanpesan komunikasi pada masyarakat berupa himbauan kebersihan lingkungan pantai. Keberhasilan pembangunan gerbang tanda masuk tersebut, tak terlepas pula dari partsipasi masyarakat sekitar bersama perangkat nagari sebagai penggerak pembangunan desa. 
Kesediaan masyarakat, khusus pemilik dan keluarga tanah bangunan rumahnya yang terpakai pada pembangunan gerbang tersebut adalah termasuk salah satu jenis bentuk partisipasi dalam pembangunan. Kemudian, penempatan gerbang tepat berada di samping kiri kantor wali nagari dan pinggiran jalan alternative tersebut, sekaligus memudahkan masyarakat mengenal keberadaan Taman Tekno terutama mereka yang melakukan kunjungan \& urusan ke Kantor Wali Nagari.

Bentuk lain sebagai kontribusi program pengabdian ini, khususnya terhadap pemerintah adalah pembuatan plank Papan berjalan (Running text) khusus untuk kebutuhan fasilitas kantor berdasarkan permintaan Pak Wali, yang bertuliskan "SELAMAT DATANG DI KANTOR WALI NAGARI KETAPIANG ........." dan dikedua sisinya diberi masing-masing logo pemerintahan Kabupaten Padang Pariaman dan Universitas negeri Padang, sebagaimana terlihat dalam Gambar 6. Gambar 7 memperlihatkan penyerahan kelengkapan kepada perangkat Nagari Ketapiang.

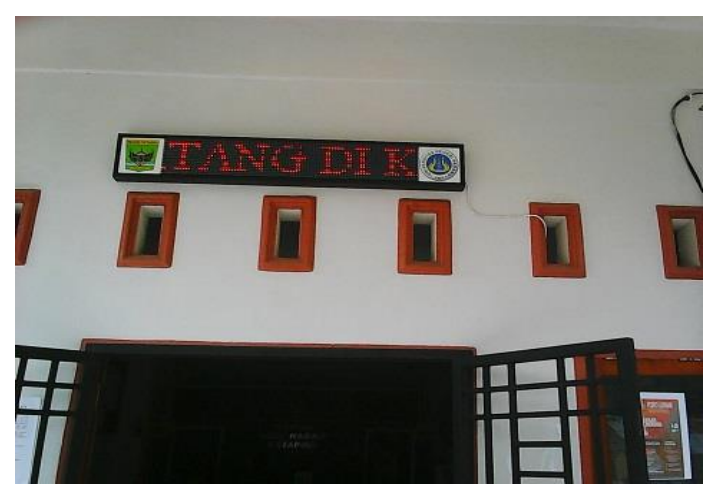

Gambar 6. "Running Text" Kantor Wali Nagari Ketaping

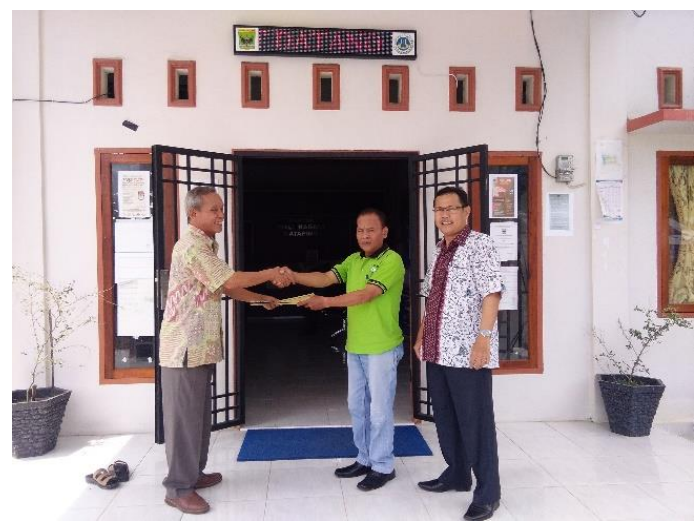

Gambar 7. Serah terima Kelengkapan ke Nagari Ketaping

\section{B. Analisis dan Evaluasi Terhadap Pelaksanaan Program Kegiatan}

Suatu hal yang menjadi tolok ukur keberhasilan program kegiatan adalah sejauh mana tampilan secara fisik hasil rekayasa daya tarik wisata dan kinerja secara teknik peran dan 
fungsinya berdampak prilaku khalayak sasaran (segi jumlah kunjungan wisata/pengunjung dan aktivitas sosial-ekonomi masyarakat).

\section{Aspek Peningkatan Jumlah Kunjungan Wisata}

Menganalisis optimalisasi daya tarik wisata antara lain tidak terlepas dari segi jumlah kunjungan, yaitu banyaknya wisatawan bepergian untuk mengunjungi daerah tujuan wisata \& menikmati obyek/attraksi yang ditawarkan sehingga memenuhi harapannya. Untuk itu, menilai kinerja bidang kepariwisataan tidak dapat dengan segera mungkin dapat dilakukan. Terlebih lagi bilamana untuk melihat \& mendapatkan informasi akan manfaat dari hasil sebuah program pembangunan, seperti multiplier effect yang ditimbulkannya secara social ekonomi, dimana membutuhkan periode waktu tertentu.

Sehubungan dengan hal itu sasaran hasil pelaksanaan program untuk peningkatan daya tarik kunjungan yang ditargetkan sehingga dapat meningkatkan jumlah kunjungan, khususnya kunjungan para siswa/mahsiswa ke obyek wisata terpadu pendidikan pada lokasi pantai Ketaping belum sempurna dapat dilakukan. Pariwisata butuh waktu untuk diperkenalkan, memerlukan kegiatan pemasaran untuk lebih diketahui, dan parawisata timbul karena adanya pencirian \& perbedaan (characteristics \& differentiation). Pengenalan taman tekno dan kelengkapan prasarana \& sarana pendukung diharapkan memberikan daya tarik dan menjadi mascot kunjungan sehingga pada gilirannya memberikan dampak terhadap jumlah kunjungan.

Sebagaimana diuraikan pada kajian pustaka bahwa suatu daerah atau kawasan dapat dikembangkan menjadi daerah tujuan wisata dan yang layak untuk dikunjungi setidaknya ada 3 (tiga) faktor, yang harus dikembangkan yaitu: (1). Adanya something to see (menarik untuk dilihat), (2). Adanya something to buy (menarik dan khas untuk dapat dibeli), dan (3). Adanya something to do (sesuatu aktivitas yang dapat dilakukan di tempat itu dan wisatawan ). Ketiga faktor tersebut dalam daerah tujuan wisata di Pantai Ketapiang dapat terpenuhi, sehingga ke depannya tinggal menunggu pihak swasta/investor berkonstribusi untuk mengembangkannya atau pihak lembaga institusi seperti Universitas Negeri Padang melalui keragaman program pengabdiannya atau penerapan iptekins melakukan kegiatan pelatihan dan penyuluhan terhadap masyarakat.

Selama ini dari hasil pengamatan tim pengabdian, daerah tujuan Wisata Pantai Ketapiang masih memposisikan kedatangan pengunjung dengan mengandalkan segi aspek something to see, pesona dan keindahan pemandangan geomorphologi pantai dan lautan, yang mana factor ini juga dimiliki oleh DTW lainnya. Justru itu, sasaran program kegiatan ini adalah meningkatkan jumlah kunjungan wisatawan tersebut dengan membangun dan mengembangkan suatu model wisata pendidikan/teknologi dengan memperkenalkan taman tekno kincir angin (Windmill Techno Park) sebagai sesuatu yang dapat dilihat dan dipelajari (something to see and learning it).

Karakteristik lainnya yang dimiliki oleh daerah tujuan wisata Pantai Ketaping adalah terdapatnya pohon-pohon pelindung dan adanya pasar ikan tradisional, sekaligus merupakan faktor-faktor pendukung pengembangan sesuatu kawasan menjadi daerah tujuan wisata, yang perlu mendapatkan sentuhan inovasi dalam kerangka meningkatkan jumlah kunjungan melalui program bersifat mengundang calon wisatawan untuk dapat menikmati \& beraktivitas melalui something to buy dan something to do, seperti tersedianya masakan spesifik dari ikan segar hasil tangkapan nelayan dan ikut serta dalam acara lelang hasil tangkapan. 


\section{Suluah Bendang: Jurnal Ilmiah Pengabdian Kepada Masyarakat}

Vol.19, No.2, 2019

Hasanuddin, Hendri Nurdin, Mansurdin, Waskito

Sebatas selama pelaksanaan program kegiatan yang dilakukan, berdasarkan pantauan skala waktu terbatas jumlah kunjungan memang belum dapat terlihat peningkatannya. Tetapi akan segi hasil pembangunan pohon-pohon kincir angin sebagai fasilitas isi taman tekno terlihat telah mulai menarik perhatian pengujung, dan di antaranya ada yang memanfaatkannya sebagai aktivitas untuk mengabadikannya menjadi sebuah kenangan berphoto bersama dan/atau selfieselfie, serta ada pula menanyakan apakah lampu yang menyala pada kincir ini berasal dari sumber matahari? (dalam aspek ini ada keingintahuan pengunjung, dan tim pengabdian menjelaskannya - hidup lampunya perantaraan kincir angin). Secara kebetulan lampu yang menyala tersebut pada model kincir angin Savonius Helik, dimana pada tatanan pengetahuan pengunjung sepertinya konstruksinya tidak familiar terhadap model kincir seperti ini. Ada pendapat dan pemikiran salah seorang anggota tim pengabdian bahwa, barangkali bagi pengunjung/masyarakat awam sesuatu yang disebut sebagai mesin kincir angin justru adalah model tradisional Belanda yang mempunyai konstruksi sudu-sudu berupa baling-baling (propeller).

\section{Tinjauan Terhadap Aktivitas Masyarakat}

Terkait dengan aktivitas kehidupan masyarakat pada lokasi obyek wisata Pantai Ketaping umumnya atau sebahagian besar bekerja \& berusaha sebagai keluarga nelayan. Menjual hasil tangkapan dari pekerjaan melaut merupakan ciri matapencaharian mereka, dimana di sekitar obyek wisata pantai terdapat lokasi pasar ikan, dan di samping itu juga di sepnajang pinggiran jalan alternatif Padang - Pariaman terdapat kios/kedai jualan kebutuhan harian masyarakat.

Mengusahakan tempat istirahat dan menawarkan jasa minuman dan makanan pada warung-warung kecil adalah juga sisi lain usaha masyarakat bidang perekonomian, Hal ini merupakan pekerjaan terkait langsung dengan aspek kepariwisataan (some to buy), seperti makanan dari hasil tangkapan ikan, minuman air kelapa muda hasil kebunnya, serta buah semangka yang banyak terdapat di daerah kenagarian tersebut.

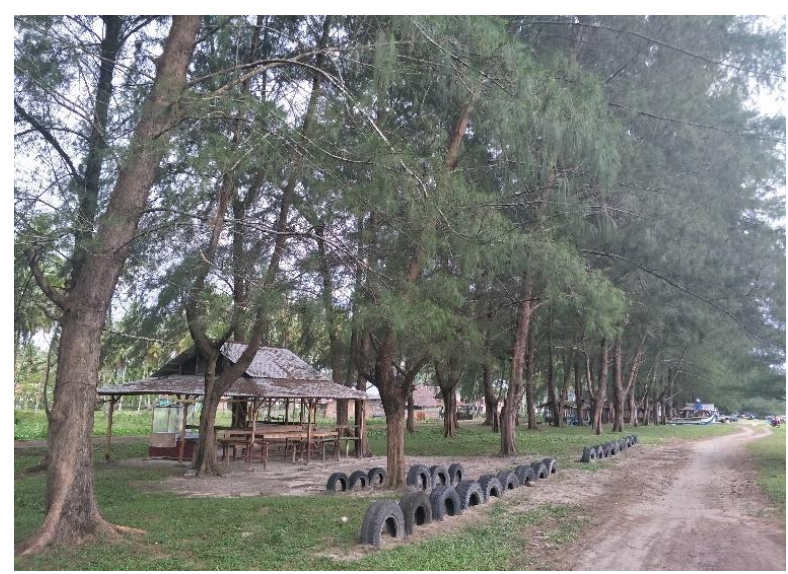

Gambar 8. Pondok Minuman Usaha Masyarakat yang Baru Berdiri di sekitar Lokasi Taman Tekno

Terhadap aspek perekonomian dan perikehidupan masyarakat ini, kondisi maju dan mundurnya usaha mereka tidak terlepas dari peningkatan jumlah kunjungan wisatawan berkunjung dan melakukan kegiatan wisata serta seberapa jauh ketersediaan obyek wisata 
yang ada menjadi daya tarik kunjungan. Hal ini tentunya, juga berpengaruh pada peningkatan jumlah dan bentuk usaha ekonomi masyarakat yang berhubungan dengan kebutuhan dan permintaan kepariwisataan. Hasil sementara, dari tinjauan selintas pada lokasi Taman Tekno Kincir Angin tersebut telah terlihat tanda-tanda adanya bentuk usaha masyarakat, berdirinya sebuah warung makanan dan minuman yang berfungsi juga tempat beristirahatan sambil rekreasi menikmati suasana pantai dimana di seputarnya tumbuh pohon pinus serta pohonpohon kincir angin seperti tampak dalam Gambar 8.

Sekaitan dengan hal ini, dibutuhkan waktu dan aktivitas pemasaran/promosi dan sosialisasi hasil penelitian dan program pengabdian/penerapan ipteks ke depannya, seperti mengadakan atraksi pertunjukan, melengkapi prasarana dan sarana pendukung lainnya, informasi melalui media serta kunjungan ke sekolah untuk mengenalkan eksistensi Taman Tekno Kincir Angin untuk sebuah referensi pembelajaran dan media pendidikan.

\section{KESIMPULAN}

Terlaksananya program kegiatan pengabdian penerapan ipteks bagi masyakat terutama untuk mengoptimalisasi daya tarik obyek wisata pendidikan taman tekno kincir angin pada daerah Pantai Panjang Nagari Ketapiang, dimana secara teknis pembuatan dan penempatan beberapa fasilitas fisik untuk peningkatan daya tarik bagi pengunjung telah memberikan dampak secara terbatas, dan butuh waktu dan wacana promosi untuk lebih meningkatkan eksistensinya. Kebutuhan pendanaan dan peningkatan kreasi dekoratif untuk melengkapi infrastruktur pertamanan sehingga memberikan kesan pesona dan daya tarik pengunjung, khususnya terkait dengan model peralatan yang bersifat memberikan pendidikan atau pembelajaran. Secara terbatas waktu secara visual, observasi (pengamatan) belum terlihat adanya peningkatan jumlah kunjungan pada obyek wisata pantai ketaping secara signifikan, sehingga masih butuh waktu untuk memperkenalkan akan daya tarik taman tekno kincir angin (windmill techno park), baik secara langsung ke sekolah maupun tidak langsung melalui media social. Oleh karena terbatasnya pendanaan program bersifat sosialisasi \& pertisipasi masyarakat oleh Tim pengabdian belum dapat menyelenggarakan kegiatan yang dapat mengikutsertakan masyarakat khususnya pedagang penjualan minuman dan makanan sekitar lokasi Taman Tekno Kincir Angin. Alokasi pendanaan yang terbatas maka program kegiatan pengabdian lebih terfokus pada aktivitas bersifat fisik mengadakan fasilitas untuk peningkatan daya tarik taman.

\section{DAFTAR PUSTAKA}

Biederman, P. S., \& Biederman, P. S. (2008). Travel and tourism: An industry primer. Pearson/Prentice Hall.

Clark, J. R. (2018). Coastal zone management handbook. CRC press.

Core Indonesia. (2016). Mendorong Percepatan Pembangunan Pariwisata di Era Jokowi. Press Release.

Hasanuddin, H., Nurdin, H., Waskito, W., \& Refdinal, R. (2018). The Combination of Coastal Resources Potential: Development of Windmill Techno Park in the Context of Edutourism and Hinterland Analysis. IOP Conference Series: Materials Science and Engineering, 335, 012059. IOP Publishing. 
Suluah Bendang: Jurnal Ilmiah Pengabdian Kepada Masyarakat

Vol.19, No.2, 2019

Hasanuddin , Hendri Nurdin, Mansurdin, Waskito

Metro-Roland, M. M., Knudsen, D. C., \& Greer, C. E. (2016). Landscape, tourism, and meaning. Routledge.

Nasional, B. P. P. (2014). Rencana pembangunan jangka menengah nasional (RPJMN) 20152019. Peraturan Presiden Republik Indonesia Nomor, 2.

Soegijoko. (2017). Keterkaitan Pusat-Pusat Pertumbuhan dengan Daerah Hinterlandnya. Press Release.

Suwantoro, G. (1997). Dasar-dasar pariwisata. Yogyakarta: Andi.

Yoeti, O. A. (2008). Perencanaan \& pengembangan pariwisata. Jakarta: PT Pradnya Paramita. 